\title{
Een explorerend onderzoek naar het takenpakket van artsen in opleiding tot specialist*
}

\author{
J. Pols, A.R. Yedema, P.M. Boendermaker
}

\section{Samenvatting}

Inleiding: In vervolgopleidingen begeleiden klinisch docenten assistenten in opleiding tot specialist (aios) bij het verwerven van Algemene Competenties. Voor hen is de vraag welke competenties bij welke taken en werkzaamheden van aios waarneembaar en verder te ontwikkelen zijn. Omdat er nog geen overzichten van het takenpakket van aios bleken te bestaan, is in dit onderzoek nagegaan welke taken en werkzaamheden aios tijdens hun vervolgopleiding hebben. De beschrijving van het takenpakket zou voldoende globaal moeten zijn om merendeels geldig te zijn voor alle vervolgopleidingen en voldoende gedetailleerd om kenmerkende verschillen zichtbaar te maken tussen aios van snijdend en beschouwend medisch specialismen, huisartsgeneeskunde en sociale geneeskunde, de vier grote groepen vervolgopleidingen.

Methode: Met een model voor beroepscompetenties als achtergrond zijn observaties en interviews uitgevoerd bij aios uit diverse vervolgopleidingen. De bevindingen zijn aangevuld met documenten en becommentarieerd door deskundigen. Het resulterende takenpakket is ter validering in een elektronische enquête voorgelegd aan aios uit de Onderwijs- en Opleidingsregio Noord en Oost Nederland.

Resultaten: Observaties en interviews resulteerden in een lijst van 59 taken en werkzaamheden. De respons op de enquête, die op basis hiervan werd samengesteld, was 34\%; de laagste respons was van sociaal geneeskundigen (16\%). Aios van één beschouwend specialisme werden niet bereikt. Zeven taken of werkzaamheden zijn aangepast, vijf zijn toegevoegd. Het resulterende takenpakket bevat 64 taken en werkzaamheden.

Conclusie en discussie: Op het gewenste detailleringsniveau is een valide overzicht verkregen van taken en werkzaamheden van aios. Ondanks diverse beperkingen is het overzicht van praktisch nut om vast te stellen welke competenties de aios bij welke taken en werkzaamheden kunnen leren en met deze informatie de opleiding beter te structureren. (Pols J, Yedema AR, Boendermaker PM. Een explorerend onderzoek naar het takenpakket van artsen in opleiding tot specialist. Tijdschrift voor Medisch Onderwijs 2005;24(5):220-229.)

\section{Inleiding}

Sinds enige jaren is het Centraal College Medische Specialismen (CCMS) actief bezig met de modernisering van de medisch specialistische vervolgopleidingen. ${ }^{1}$ Inmiddels zijn moderniseringsactiviteiten gestart rond alle onderwijskundige facetten van de vervolgopleidingen: doelen (ge- formuleerd in de vorm van competenties), onderwijsmiddelen en docenten en het systeem van toetsen en beoordelen.

Inhoudelijk heeft het CCMS in zeven competentiegebieden en 28 competenties vastgelegd wat elke assistent zich in de loop van de opleiding eigen moet maken. ${ }^{2}$ Deze Algemene Competenties zijn overge-

\footnotetext{
* Het hier gepresenteerde artikel is een gecondenseerde versie van een deel van de doctoraalscriptie van A.R.Yedema, getiteld Het ervaren curriculum van de medische vervolgopleidingen (Groningen: AZG; 2004). De volledige scriptie is te verkrijgen bij de eerste auteur.
} 
nomen door het College voor Huisartsgeneeskunde en Verpleeghuisgeneeskunde en het College voor Sociale Geneeskunde. Ze zijn opgenomen in de vernieuwde kaderbesluiten van deze drie colleges, wat betekent dat aios in elke vervolgopleiding deze competenties moeten verwerven.

Onderwijskundig gezien hebben de veranderingen te maken met een wending van input georiënteerde opleidingen naar output georiënteerde opleidingen. Daarbij zijn het niet langer de duur van de stages, de aantallen patiënten of het gevolgde cursorisch onderwijs (de input) die bepalen of aios kunnen worden geregistreerd als medisch specialist, maar het effect van deze activiteiten op hun functioneren in de patiëntenzorg (de output). Voor opleiders en supervisoren betekent deze wending dat ze - veelal vaker dan nu het geval is - het functioneren van aios in de dagelijkse patiëntenzorg moeten observeren en toetsen. Alleen daar kan worden vastgesteld in welke mate aios zich de Algemene Competenties al hebben eigen gemaakt en op welke punten zij zich nog moeten verbeteren. Een complicatie daarbij is dat werkzaamheden en competenties niet hetzelfde zijn. Het CCMS definieert competenties als: "[...] clusters van vaardigheden, kennis, attituden, eigenschappen en inzichten. Ze zijn verbonden met activiteiten of taken. [...]."2 Competenties zijn dus noodzakelijke voorwaarden om werkzaamheden in de patiëntenzorg uit te kunnen voeren, ze worden daarbij veelal geïntegreerd gebruikt en worden in de uitvoering van werkzaamheden zichtbaar. Een praktische vraag voor individuele opleiders en supervisoren is welke competenties bij welke werkzaamheden kunnen worden geobserveerd. Om zoveel mogelijk de werkzaamheden van aios ook te kunnen benutten als opleidingsmomenten is het nodig om een overzicht te hebben over al hun werkzaamheden. Uitgebreid literatuuronderzoek leidt tot de conclusie dat zo'n overzicht niet voorhanden is. ${ }^{3}$ Dat vormt de directe aanleiding tot het explorerend onderzoek waarover hier wordt gerapporteerd. De vraagstelling luidt: Welke taken en werkzaamheden hebben artsen in opleiding tot specialist?

Wat betreft het detailleringsniveau is gestreefd naar taken en werkzaamheden die zo globaal zijn dat het merendeel geldig is voor alle vervolgopleidingen. Aan de andere kant is geprobeerd om ze zo gedetailleerd te beschrijven dat kenmerkende verschillen zichtbaar worden tussen de werkzaamheden van aios uit vier grote groepen vervolgopleidingen: snijdend en beschouwend medisch specialismen, huisartsen en sociaal geneeskundigen. ${ }^{4}$

\section{Theoretisch kader}

Het onderzoek beoogt een zo volledig mogelijk overzicht te geven van de taken en werkzaamheden van aios. Om systematisch onderzoek te kunnen doen en lacunes te voorkomen, is het wenselijk uit te gaan van een modelmatige beschrijving van de werkzaamheden die mogen worden verwacht van mensen die arbeid verrichten.

In principe komen de zeven domeinen van de Algemene Competenties in aanmerking als modelmatige beschrijving van de werkzaamheden van medici en aios. Ze zijn echter gebaseerd op de zeven rollen van medisch specialisten die voortkwamen uit het Canadese project CanMEDS 2000. ${ }^{2}$ Die zijn het resultaat van een onderzoek naar wensen van consumenten over medisch specialisten. De rollen (en dus ook de Algemene Competenties) zijn niet gebaseerd op een taakanalyse van de werkzaamheden van medisch specialisten en daarom voor ons onderzoek niet bruikbaar.

In Nederland wordt, met name in het secundair beroepsonderwijs, veel gebruik gemaakt van een model dat is ontwikkeld door Onstenk en is aangepast door 
ACOA, de Adviescommissie Onderwijs- en Arbeidsmarkt. ${ }^{5-6}$ ACOA noemt de taken en werkzaamheden van een beroep "kernopgaven" en definieert die als: "[...] de centrale opgaven en problemen waar een beroepsbeoefenaar regelmatig mee in aanraking komt en die kenmerkend zijn voor het beroep, die aangepakt moeten worden binnen een of meerdere specifieke organisatorische en sociaal-communicatieve contexten, waarbij van de beroepsbeoefenaar een oplossing en een aanpak worden verwacht."

Ook ACOA stelt vast dat iemand bepaalde competenties nodig heeft om de kernopgaven van een beroep uit te kunnen voeren en definieert competenties als: "[...] het vermogen van een individu om de kernopgaven van een beroep op een adequate, procesgerichte en productgerichte wijze aan te pakken. Competenties zijn multidimensionaal, gestructureerd en onderling samenhangend."6 Deze definitie bevat, als een van de weinige, vrijwel alle kenmerken waarvan de Onderwijsraad heeft aangegeven dat die in een definitie van het begrip competentie zouden moeten voorkomen. ${ }^{7}$ Naast de brede toepassing zijn er voor het gebruik van het model van het ACOA dus ook inhoudelijk goede argumenten.

ACOA brengt de competenties die nodig zijn om de kernopgaven van een beroep aan te kunnen pakken onder in vier groepen:

1. Vakmatige- en methodische beroepscompetenties.

2. Bestuurlijk-organisatorische en strategische competenties.

3. Sociaal-communicatieve en normatiefculturele competenties.

4. Leer- en vormgevingscompetenties.

Het model is goed toepasbaar op taken en werkzaamheden van aios. Daarin staat het contact met patiënten en het toepassen van medisch inhoudelijke kennis en ervaring centraal (competentiegroep 1). Daarnaast zijn er kernopgaven op het gebied van bijvoorbeeld - samenwerking met verpleeg- kundigen en paramedici, de organisatie van het werk (competentiegroep 2), het hanteren van (hiërarchische) werkverhoudingen, het vertegenwoordigen van de professie (competentiegroep 3) en bijleren en bijscholen (competentiegroep 4).

\section{Methode}

\section{Setting en onderzoeksgroep}

Het onderzoek is uitgevoerd in de Onderwijs- en OpleidingsRegio (OOR) Noord en Oost Nederland, grofweg overeenkomend met de provincies Drenthe, Friesland, Groningen en Overijssel. De onderzoekspopulatie bestaat uit alle aios in de OOR die op dit moment een vervolgopleiding volgen tot medisch specialist, huisarts of sociaal geneeskundige. De onderzoeksgroep is op twee manieren ingeperkt:

1. Alleen de aios in opleiding binnen een specialisme met direct patiëntencontact zijn benaderd (dus niet de aios pathologie, medische microbiologie en radiologie).

2. Voor een OOR zijn namen en adressen van aios niet centraal beschikbaar. Om pragmatische redenen is de onderzoeksgroep daarom beperkt tot alle aios huisartsgeneeskunde en sociale geneeskunde en zijn van de medisch specialistische vervolgopleidingen de aios benaderd die hun opleiding volgen in het Universitair Medisch Centrum Groningen. Van deze laatste groep zijn ook de aios benaderd die in het kader van een geclusterde opleiding een deel van hun opleiding in een algemeen opleidingsziekenhuis volgen.

\section{Gegevensverzameling}

Een initieel takenpakket is opgesteld op basis van observaties, interviews, documenten en deskundigen. Dit takenpakket is gevalideerd met behulp van een elektronische enquête. 


\section{Initieel takenpakket}

De dagelijkse werkzaamheden van aios uit verschillende vervolgopleidingen zijn gedurende één werkdag geobserveerd. Feitelijke beschrijvingen van werkzaamheden en subjectieve indrukken van de onderzoeker zijn in een logboek vastgelegd. Aan het eind van een observatiedag is een semi-gestructureerd interview afgenomen. Daarbij zijn verhelderende vragen gesteld over de waarnemingen en zijn de vier competentiegroepen van het ACOA systematisch bevraagd. De inhoud van observaties en interviews is mede bepaald door aandachtspunten die naar voren kwamen in de voorgaande observaties en interviews. Met interviews en observaties werd doorgegaan tot het moment dat informatieverzadiging optrad: een volgende observatie en interview leverde geen wezenlijke nieuwe taken en activiteiten meer op. ${ }^{8}$

Om structuur aan te brengen in de gegevens van de observaties en interviews is een inhoudsanalyse uitgevoerd. ${ }^{8}$ Alle taken en werkzaamheden zijn in eerste instantie van een label voorzien in de vorm van een korte omschrijving. Gelijksoortige taken en werkzaamheden zijn vervolgens samengebracht onder een overkoepelend label. Waar nodig en relevant is dit proces herhaald tot alle taken en werkzaamheden konden worden ondergebracht in niet-overlappende categorieën. In deze fase van het onderzoek is gebruik gemaakt van Atlasti, een softwarepakket dat de analyse van kwalitatieve gegevens ondersteunt. ${ }^{9}$

De bevindingen uit de observaties en interviews zijn aangevuld met informatie uit documenten (tabel 1) en van deskundigen. De onderverdelingen van taken en werkzaamheden die in de documenten worden genoemd, werden geïnventariseerd en gebruikt als aanvulling op of als systematisering van het zich ontwikkelende takenpakket.
Tabel 1. Documenten gebruikt bij het opstellen van het takenpakket.

- Het basispakket van de gynaecoloog. ${ }^{12}$

- Het basistakenpakket van de huisarts. ${ }^{13}$

- Raamplan 2001 artsopleiding. ${ }^{14}$

- Notitie modernisering. ${ }^{15}$

- AZGcahiers-6 Resultaat- en gedragsgericht werken in het AZG. ${ }^{16}$

- Observaties arts-assistenten kindergeneeskunde AZG. ${ }^{17}$

- Coachen op resultaat en gedrag. ${ }^{18}$

- Doelstellingen voor communicatie in de basisopleiding tot arts. ${ }^{19}$

Er zijn drie deskundigen geraadpleegd: een specialist op het gebied van competenties en leren op de werkplek, een AIO met als onderzoeksterrein taak- en functiedifferentiatie binnen de gezondheidszorg en een medewerker van het Universitair Medisch Centrum Groningen die betrokken is bij taak- en functieomschrijving. Zij hebben onafhankelijk van elkaar commentaar en aanvullingen gegeven op de bevindingen uit de observaties en interviews. Hun suggesties zijn overgenomen wanneer zij alle drie dezelfde soort aanpassingen voorstelden. ${ }^{10}$

\section{Verdere validering: enquête}

Alle taken en werkzaamheden uit het voorgaande deel van het onderzoek zijn opgenomen in een elektronische enquête met als vraag: "Hoe vaak voert u deze taak/ werkzaamheid uit?" De antwoordmogelijkheden waren: 1 = nooit; 2 = jaarlijks; $3=$ maandelijks; $4=$ wekelijks of $5=$ dagelijks. In de enquête is de aios de mogelijkheid gegeven om suggesties te doen voor aanvullingen op het takenpakket. Als pilot is de enquête voorgelegd aan zeven aios en waar nodig zijn naar aanleiding daarvan formuleringen en schermpresentatie van de enquête aangepast.

Opleiders is verzocht om medewerking bij het verspreiden van de enquête. Via hun secretariaten is aan alle aios per e-mail 
het verzoek verstuurd om mee te werken en is het internetadres van de definitieve enquête beschikbaar gesteld. Na twee en na vier weken zijn reminders verstuurd. $\mathrm{Bij}$ de laatste reminder is doorgevraagd naar de reden van eventuele non-respons.

Voor elke taak/werkzaamheid is het gewogen gemiddelde berekend van de frequentie waarin die wordt uitgevoerd. Dit is gedaan voor de hele groep respondenten en voor de groepen aios van snijdend en beschouwend medisch specialismen, huisartsgeneeskunde en sociale geneeskunde.

Van de opmerkingen is onafhankelijk door twee van de auteurs (J. Pols en A.R. Yedema) beoordeeld of er consequenties voor het takenpakket aan verbonden moesten worden. Verschillen van mening zijn bediscussieerd tot er consensus bestond.

Tabel 2. Taken en werkzaamheden met hun frequentie van uitvoeren.

\begin{tabular}{|c|c|c|c|c|c|}
\hline \multirow[t]{2}{*}{ Taken en werkzaamheden } & \multicolumn{5}{|c|}{ Frequentie van uitvoeren ${ }^{*}$} \\
\hline & $1^{* *}$ & 2 & 3 & 4 & 5 \\
\hline Samenwerken met ondersteunend personeel, zoals secretaresses & 4,89 & 4,82 & 4,93 & 4,89 & 5,00 \\
\hline Het medisch dossier van patiënten bijhouden & 4,87 & 4,81 & 4,94 & 4,86 & 4,93 \\
\hline Klachtgerichte anamnese afnemen & 4,85 & 4,86 & 4,78 & 4,97 & 4,93 \\
\hline Beleid opstellen voor een patiënt & 4,77 & 4,87 & 4,74 & 4,95 & 3,86 \\
\hline Lichamelijk onderzoek uitvoeren & 4,73 & 4,82 & 4,63 & 4,97 & 4,27 \\
\hline Een algemene anamnese (screening) uitvoeren & 4,67 & 4,69 & 4,69 & 4,64 & 4,47 \\
\hline De hulpvraag van een patiënt verhelderen & 4,63 & 4,45 & 4,64 & 5,00 & 4,67 \\
\hline De resultaten van het aanvullend onderzoek interpreteren & 4,55 & 4,72 & 4,61 & 4,75 & 2,79 \\
\hline Formulieren invullen en/of ondertekenen & 4,53 & 4,68 & 4,57 & 4,41 & 3,87 \\
\hline Therapeutisch beleid uitvoeren & 4,49 & 4,75 & 4,56 & 4,73 & 2,00 \\
\hline Aanvullend onderzoek aanvragen & 4,48 & 4,62 & 4,55 & 4,78 & 2,67 \\
\hline $\begin{array}{l}\text { Binnen de marges een planning maken van mijn } \\
\text { werkzaamheden }\end{array}$ & 4,43 & 4,29 & 4,58 & 4,37 & 4,60 \\
\hline Privé-leven en werk van elkaar scheiden & 4,42 & 4,52 & 4,52 & 4,36 & 3,50 \\
\hline $\begin{array}{l}\text { Mijn manier van werken aanpassen aan de persoonlijkheid van } \\
\text { patiënten }\end{array}$ & 4,38 & 4,48 & 4,30 & 4,39 & 4,27 \\
\hline Consulten doen bij patiënten met een nieuw probleem & 4,34 & 4,17 & 4,26 & 4,89 & 4,27 \\
\hline $\begin{array}{l}\text { Tegenover patiënten duidelijk maken wat ze wel en niet van mij } \\
\text { kunnen verwachten }\end{array}$ & 4,32 & 4,45 & 4,17 & 4,19 & 4,73 \\
\hline Brieven schrijven en/of dicteren & 4,29 & 4,19 & 4,53 & 4,03 & 4,20 \\
\hline $\begin{array}{l}\text { Bij het bereiken van de grenzen van mijn medische } \\
\text { bekwaamheid een supervisor/opleider raadplegen }\end{array}$ & 4,29 & 4,49 & 4,35 & 4,21 & 3,00 \\
\hline Samenwerken met verpleegkundigen & 4,24 & 4,97 & 4,57 & 2,66 & 2,53 \\
\hline Voorbereiden op een consult/spreekuur/visite/huisbezoek & 4,24 & 3,86 & 4,31 & 4,74 & 4,60 \\
\hline $\begin{array}{l}\text { Omgaan met onverwachte gebeurtenissen die mijn planning } \\
\text { door de war gooien }\end{array}$ & 4,16 & 4,25 & 4,34 & 3,74 & 3,79 \\
\hline Zelf lacunes in mijn kennis en vaardigheden vaststellen & 4,13 & 4,24 & 4,20 & 3,85 & 3,86 \\
\hline Zorgen dat ik de lacunes in mijn kennis en vaardigheden opvul & 4,01 & 4,07 & 4,05 & 4,03 & 3,43 \\
\hline Een (andere) specialist in consult vragen & 3,94 & 4,08 & 4,01 & 4,05 & 2,53 \\
\hline Medische verrichtingen uitvoeren & 3,94 & 4,51 & 3,92 & 3,81 & 1,33 \\
\hline
\end{tabular}




\begin{tabular}{|c|c|c|c|c|c|}
\hline \multirow[t]{2}{*}{ Taken en werkzaamheden } & \multicolumn{5}{|c|}{ Frequentie van uitvoeren* } \\
\hline & $1^{* *}$ & 2 & 3 & 4 & 5 \\
\hline Consulten doen bij patiënten met acute problematiek & 3,86 & 4,12 & 3,77 & 4,30 & 1,87 \\
\hline $\begin{array}{l}\text { De planning van mijn werkzaamheden afstemmen in overleg } \\
\text { met collega's }\end{array}$ & 3,85 & 3,95 & 4,04 & 3,61 & 2,93 \\
\hline De grenzen van mijn specialisme bewaken & 3,82 & 3,86 & 3,89 & 3,70 & 3,57 \\
\hline Zelf een patiënt overdragen & 3,80 & 4,44 & 4,11 & 2,65 & 1,60 \\
\hline $\begin{array}{l}\text { Patiëntgegevens verwerken met behulp van een } \\
\text { computerprogramma }\end{array}$ & 3,76 & 3,78 & 3,36 & 4,40 & 4,27 \\
\hline Gesprekken voeren met familie of bekenden van patiënten & 3,65 & 3,71 & 4,05 & 3,22 & 2,27 \\
\hline Voorbereiden van een patiëntoverdracht & 3,63 & 4,12 & 4,11 & 2,37 & 1,73 \\
\hline Met feedback omgaan die ik van collega's krijg & 3,62 & 3,88 & 3,38 & 3,86 & 2,93 \\
\hline $\begin{array}{l}\text { Samenwerken met paramedici, zoals diëtisten en } \\
\text { fysiotherapeuten }\end{array}$ & 3,60 & 3,79 & 3,93 & 2,86 & 2,64 \\
\hline Samenwerken in een multidisciplinair team & 3,56 & 3,53 & 4,05 & 2,40 & 3,93 \\
\hline $\begin{array}{l}\text { Gesprekken voeren met patiënten voor het verkrijgen van } \\
\text { toestemming }\end{array}$ & 3,54 & 3,96 & 3,58 & 2,72 & 3,07 \\
\hline $\begin{array}{l}\text { Mijn plaats als arts-assistent afbakenen binnen de hiërarchie van } \\
\text { mijn afdeling/praktijk }\end{array}$ & 3,26 & 3,57 & 3,42 & 2,97 & 1,43 \\
\hline Co-assistenten superviseren & 3,25 & 3,90 & 3,79 & 1,23 & 1,87 \\
\hline Diensten doen & 3,24 & 3,44 & 3,23 & 3,70 & 1,07 \\
\hline Feedback geven op het handelen van collega's & 3,23 & 3,57 & 3,03 & 3,17 & 2,67 \\
\hline De opname van een patiënt regelen & 3,21 & 3,46 & 3,31 & 3,37 & 1,07 \\
\hline Omgaan met ongewenst gedrag van patiënten & 3,14 & 3,24 & 3,13 & 3,14 & 2,60 \\
\hline Slecht nieuws gesprekken voeren met patiënten & 3,01 & 3,19 & 3,04 & 2,61 & 2,93 \\
\hline Ingrepen/operaties voorbereiden & 3,00 & 4,35 & 1,95 & 3,22 & 1,00 \\
\hline Ingrepen/operaties uitvoeren & 2,93 & 4,33 & 1,76 & 3,33 & 1,00 \\
\hline Me aanpassen aan een nieuwe werkomgeving & 2,53 & 2,60 & 2,57 & 2,56 & 1,79 \\
\hline Een referaat houden & 2,48 & 2,73 & 2,57 & 2,15 & 1,43 \\
\hline $\begin{array}{l}\text { Veranderingen voorstellen die zorgen voor kwaliteitsverbetering } \\
\text { van mijn werkomgeving }\end{array}$ & 2,39 & 2,36 & 2,53 & 2,18 & 2,36 \\
\hline Jongerejaars arts-assistenten superviseren & 2,33 & 3,18 & 2,22 & 1,09 & 1,33 \\
\hline Onderzoek doen & 2,32 & 2,74 & 2,39 & 1,53 & 1,57 \\
\hline Leiding geven aan een team & 2,26 & 2,84 & 2,14 & 1,37 & 2,07 \\
\hline Lesgeven aan co-assistenten & 2,13 & 2,64 & 2,29 & 1,09 & 1,00 \\
\hline $\begin{array}{l}\text { Samenwerken met mensen die geestelijke ondersteuning bieden } \\
\text { aan patiënten, zoals pastors }\end{array}$ & 1,86 & 1,92 & 2,16 & 1,31 & 1,33 \\
\hline Een artikel schrijven & 1,82 & 1,44 & 1,69 & 1,76 & 1,00 \\
\hline Leiding geven aan een afdeling/praktijk & 1,76 & 2,01 & 2,00 & 1,24 & 1,21 \\
\hline Lesgeven aan arts-assistenten & 1,56 & 1,69 & 1,95 & 1,74 & 1,27 \\
\hline Gesprekken voeren met patiënten over euthanasie & 1,44 & 1,42 & 1,40 & 1,72 & 1,00 \\
\hline Periodieke gezondheidskeuringen uitvoeren & 1,35 & 1,04 & 1,13 & 2,22 & 1,93 \\
\hline $\begin{array}{l}\text { * Op een } 5 \text {-puntsschaal van } 1=\text { nooit tot } 5=\text { dagelijks. } \\
\text { ** } 1=\text { alle respondenten; } 2=\text { snijdende specialismen; } 3=\text { beschou } \\
4=\text { huisartsgeneeksunde; } 5=\text { sociale geneeskunde. }\end{array}$ & 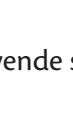 & 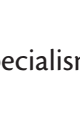 & & & \\
\hline
\end{tabular}




\section{Resultaten}

\section{Initieel takenpakket}

Bij de observatie en het interview van de zevende aios ontstond informatieverzadiging: het leverde geen wezenlijke nieuwe taken en werkzaamheden meer op. Daarop is afgezien van verdere observaties en interviews. De zeven aios volgden de opleidingen chirurgie, obstetrie en gynaecologie, revalidatiegeneeskunde, interne geneeskunde, psychiatrie, huisartsgeneeskunde en sociale geneeskunde. Het takenpakket uit deze fase van het onderzoek bevat 59 taken en werkzaamheden (tabel 2).

\section{Verdere validering: enquête}

Alle opleiders, behalve die van één van de grotere beschouwende specialismen, verleenden hun medewerking aan de verspreiding van de enquête. Via hun secretariaten is de enquête voorgelegd aan 615 aios (zie tabel 3).

In totaal zijn 236 enquêtes (38\%) geretourneerd. Daarvan zijn er 210 ingevuld en beoordeelbaar (respons $34 \%$ ). De respons van aios uit verschillende groepen specialismen varieert: die van aios uit beschouwende specialismen is het hoogst (53\%), gevolgd door die uit de snijdende (32\%), de huisartsgeneeskundige (30\%) en de sociaal geneeskundige specialismen (16\%). Van de resterende 26 enquêtes waren er elf niet beoordeelbaar en vijftien waren van aios die aangaven waarom zij de enquête niet invulden, het merendeel van hen (10) meldde tijdsgebrek.
Uit tabel 2 blijkt dat de frequentie waarin taken en werkzaamheden worden uitgevoerd geleidelijk afloopt van vrijwel dagelijks $(4,89)$ tot vrijwel nooit $(1,35)$. De vijf meest frequent (dagelijks) uitgevoerde taken zijn in aflopende frequentie: samenwerken met ondersteunend personeel, zoals secretaresses; het medisch dossier van patiënten bijhouden; klachtgerichte anamnese afnemen; beleid opstellen voor een patiënt, en; lichamelijk onderzoek uitvoeren.

De vijf minst frequent uitgevoerde taken worden elk minder dan eens per jaar uitgevoerd. In aflopende frequentie gaat het om: een artikel schrijven; leiding geven aan een afdeling/praktijk; lesgeven aan arts-assistenten; gesprekken voeren met patiënten over euthanasie, en; periodieke gezondheidskeuringen uitvoeren.

Er zijn verschillen in de frequentie waarmee de taken door aios uit de vier groepen specialismen worden uitgevoerd. Het samenwerken met verpleegkundigen gebeurt bijvoorbeeld frequent door aios uit snijdende en niet-snijdende specialismen en weinig frequent door aios huisartsgeneeskunde en sociale geneeskunde. Met name de groep aios sociale geneeskunde rapporteert bij een aantal taken lage frequenties, van vijf taken geven zij aan die nooit $(1,00)$ uit te voeren (zie tabel 2$)$.

Er zijn 54 suggesties gedaan voor aanvullingen op het takenpakket. Het merendeel van de suggesties heeft niet tot veranderingen geleid. Het gaat daarbij om suggesties voor taken die (1) al met een algemenere formu-

Tabel 3. Samenstelling onderzoeksgroep en respons.

\begin{tabular}{lcc}
\hline Specialisme & Onderzoeksgroep N & Respons N (\%) \\
\hline Snijdend & 245 & $79(32,2)$ \\
Beschouwend & 146 & $78(53,4)$ \\
Huisartsgeneeskundig & 129 & $38(29,5)$ \\
Sociaal geneeskundig & 95 & $15(15,8)$ \\
\cline { 2 - 3 } Totaal & $\mathbf{6 1 5}$ & $\mathbf{2 1 0}(34,1)$ \\
\hline
\end{tabular}


lering in de vragenlijst zijn opgenomen of (2) specifiek zijn voor één van de opleidingen. Een voorbeeld van het eerste is de suggestie 'bestralingsplannen opstellen', wat een verbijzondering is van de taak 'beleid opstellen voor een patiënt'. Een voorbeeld van het tweede is de suggestie van een aios sociale geneeskunde: 'omgaan met de commerciële instelling van managers'. De opmerkingen leidden tot herformulering in zeven taken en vijf aanvullingen op het takenpakket (tabel 4). Het uiteindelijke takenpakket bevat 64 taken en werkzaamheden.

\section{Conclusie en discussie}

Met dit onderzoek is een overzicht gerealiseerd van het takenpakket van aios dat dekkend is voor de taken en werkzaamheden die zij tijdens hun opleiding hebben. De gekozen combinatie van werkwijzen - theoretisch kader, observaties, interviews, documenten, deskundigen, pilotstudy, enquête - staat er borg voor dat het takenpakket een goede afspiegeling vormt van de praktijk. De enquête laat bovendien zien dat het takenpakket voldoende globaal is om geldig te zijn voor aios uit de meeste vervolgopleidingen en dat het voldoende gedetailleerd lijkt om verschillen tussen groepen specialismen te laten zien.

Bij het gevonden takenpakket kunnen verschillende kanttekeningen geplaatst worden: aios uit een van de grote beschouwende specialismen ontbreken, de gemiddelde respons is matig en met name de sociaal geneeskundigen zijn slecht vertegenwoordigd. Het ontbreken van aios uit een van de beschouwende specialismen zorgt ervoor dat niet bekend is of het gevonden takenpakket geldig is voor deze hele groep specialismen. Er mag aangenomen worden dat dat wel het geval is, omdat het gevonden takenpak-

Tabel 4. Aanpassingen en aanvullingen op het takenpakket naar aanleiding van de enquête.

\section{Aanpassingen van de oorspronkelijke formulering (aanpassingen cursief weergegeven)}

- Beleid opstellen voor een patiënt en de patiënt adviseren/ voorlichten over beleidsopties.

- Zorgen dat ik de lacunes in mijn kennis en vaardigheden opvul (bijv. door het volgen van cursorisch onderwijs of het bijhouden van literatuur).

- Een andere arts in consult vragen.

- Zelf een patiënt presenteren op een patiëntoverdracht of bespreking.

- Voorbereiden van een patiëntoverdracht/ patiëntbepreking.

- Gesprekken voeren met patiënten of hun wettelijke vertegenwoordigers voor het verkrijgen van toestemming (bijv. voor bepaald onderzoek, een donatie of operaties).

- Lesgeven (bijv. aan co-assistenten, arts-assistenten, verpleegkundigen).

- Een collega adviseren die mij in consult vraagt.

- Overleggen met verwijzers.

- Telefonisch spreekuur doen.

- Omgaan met derden die aanwezig zijn bij contacten die ik heb met patiënten.

- Werken in teamverband.

- Taken binnen de beschikbare tijd afronden. 
ket redelijk globaal is en het voor aios uit alle andere specialismen geldig is. Over de non-respons is niet veel bekend. Wat bekend is, laat zien dat die voornamelijk wordt toegeschreven aan tijdgebrek, een factor die geen invloed heeft op de afhankelijke variabele in het onderzoek, het takenpakket. ${ }^{11}$ De respons van de aios sociale geneeskunde is het laagst en zij hebben het grootste aantal taken en werkzaamheden met (zeer) lage frequenties. Ze plaatsten bovendien diverse kanttekeningen bij het takenpakket. Het is daarmee de vraag of het gevonden takenpakket voor hen een goede afspiegeling vormt van hun taken en werkzaamheden.

De besproken beperkingen laten onverlet dat het merendeel van de gevonden taken en werkzaamheden voor alle aios de kern vormt van hun vervolgopleiding. Tijdens het uitvoeren van deze taken passen zij de Algemene Competenties toe én maken zij zich die verder eigen. Met het gevonden takenpakket kan de brug geslagen worden tussen takenpakket en competenties. Het is daarvoor op drie manieren van praktisch nut:

1. Inhoudelijk biedt het de mogelijkheid na te gaan welke Algemene Competentie(s) bij welke taak specifiek kan worden geobserveerd door klinisch docenten.

2. Procesmatig kan het worden gebruikt om na te gaan hoe in een vervolgopleiding aios optimaal (begeleid worden als zij) de beschreven taken leren.

3. Procedureel kan het worden gebruikt om de opleiding beter te structureren.

Naar aanleiding van het voorgaande willen wij een aantal aanbevelingen doen voor vervolgonderzoek:

- Voor het verder funderen van het gevonden takenpakket is het nodig de dataverzameling aan te vullen met die van aios uit het ontbrekende specialisme en extra aandacht (inhoudelijk en wat respons betreft) te besteden aan de aios sociale geneeskunde. Bij vervolgonderzoek kan ook nader onderzocht worden of het takenpakket inderdaad vodloende gedetailleerd is om verschillen zichtbaar te maken in het takenpakket van aios uit verschillende groepen specialismen.

- Om vast te stellen of het eerder veronderstelde praktisch nut van het takenpakket ook daadwerkelijk bestaat, zou hiernaar verder onderzoek gedaan kunnen worden.

- Het is niet duidelijk of de taken en werkzaamheden van aios een goede afspiegeling vormen van de taken en werkzaamheden die zij na hun registratie als zelfstandig specialist uit zullen moeten voeren. Nader onderzoek naar het takenpakket van medisch specialisten kan op dit punt uitkomst bieden.

\section{Dank}

Zonder de hulp van vele aios zou dit onderzoek niet plaats hebben kunnen vinden. Daarnaast zijn de auteurs dank verschuldigd aan drs. G.G. Toren (universitair docent Andragogiek, Rijksuniversiteit Groningen) voor zijn suggesties bij de opzet en uitvoering van het onderzoek en aan dr. J. Onstenk (CINOP/Hogeschool INHOLLAND), drs. P. Remmelts en drs. M. Knip (beide Wenckebach Instituut UMCG) voor hun kritisch commentaar tijdens het opstellen van het takenpakket.

\section{Literatuur}

1. Bleker OP, Hoorntje JCA, Schelfhout VJ. Beter en leuker: CCMS ontvouwt plannen voor de vervolgopleiding van medisch specialisten. Med Contact 2004;59(43):1692-5.

2. KNMG. Algemene competenties van de medisch specialist [monograph op internet]. [cited 14 september 2005]. Beschikbaar op: http://knmg. artsennet.nl/uri/?uri=AMGATE_6059_100_TICH_ R158679960183152.

3. Voor de periode tot 2002, zie: Pols J. De beroepsvoorbereiding van studenten geneeskunde. Verkenningen op het gebied van chronisch zieken [dissertation]. Groningen: Rijksuniversiteit Groningen; 2002. Het onderzoek is met hetzelfde resultaat opnieuw uitgevoerd voor de periode 2002-juli 2005. 
4. Heineman MJ. Programmabeschrijving bachelorfase G2010. Groningen: OWI/FMW Rijksuniverstiteit Groningen; 2003.

5. Onstenk JHAM. Lerend leren werken: brede vakbekwaamheid en de integratie van leren, werken en innoveren [dissertation]. Delft: Eburon; 1997.

6. Adviescommissie Onderwijs-Arbeidsmarkt. Een wending naar kerncompetenties. De betekenis van kerncompetenties voor de versterking van de kwalificatiestructuur secundair beroepsonderwijs [advice]. 's-Hertogenbosch; ACOA: 1999.

7. Merriënboer JJG van, Klink MR van der, Hendriks M. Competenties: van complicaties tot compromis. Over schuifjes en begrenzers. Den Haag: Onderwijsraad; 2002. Studie in opdracht van de Onderwijsraad nr. 20020382/589.

8. Baarda DB, Goede MPM de, Teunissen J. Basisboek kwalitatief onderzoek: praktische handleiding voor het opzetten en uitvoeren van kwalitatief onderzoek. Houten: Stenfert Kroese; 2001.

9. Muhr T. ATLAS/ti - A prototype for the support of text interpretation. Qual Sociol 1991;14(4):349-71.

10. Wester F. Strategieën voor kwalitatief onderzoek. 3rd ed. Bussum: Coutinho; 1995.

11. Huisman JME. Item nonresponse: occurrence, causes, and imputation of missing answers to test items [dissertation]. Leiden: DSWO Press; 1999.

12. Het Basispakket van de gynaecoloog [paper]. Utrecht: Nederlandse Vereniging voor Obstetrie en Gynaecologie; 1999.

13. Mäkel H, Barents CJ, Bruins $\mathrm{CP}$, editors. Basistakenpakket van de huisarts. Utrecht: Landelijke Huisartsen Vereniging; 1988.

14. Metz JCM, Verbeek-Weel AMM, Huisjes HJ. Raamplan 2001 artsopleiding: bijgestelde eindtermen van de artsopleiding. Nijmegen: Mediagroep Nijmegen; 2001.
15. Bleker OP, Plasmans CMT. Notitie modernisering [meeting paper]. Utrecht: KNMG/CCMS; 2003. CCMS/KB 03-209.

16. Resultaat- en gedragsgericht werken in het AZG. In: Leeuwen-Seelt EI van, Broerse LJ, Ekkelboom JCAM, Jongste MJL de, Meininger AK, Ruiter JH de. AZGcahiers-6. Groningen: Academisch Ziekenhuis Groningen; 1999.

17. Rozema H. Observaties arts-assistenten kindergeneeskunde AZG [internal paper]. Groningen: Academisch Ziekenhuis Groningen, Stafgroep O\&O; 2002.

18. Broerse LJ. Coachen op resultaat en gedrag [internal paper]. Groningen: Academisch Ziekenhuis Groningen; 1998.

19. Koppelman GH, Aukes LC, Bootsma-de Langen AM, Kreeftenberg HG, Pols J, Venekamp R, et al. Doelstellingen voor communicatie in de basisopleiding tot arts. In: Cate ThJ ten, et al, editors. Gezond Onderwijs-5. Houten: Bohn Stafleu Van Loghum; 1996. p. 213-9.

De auteurs:

Dr. J. Pols is als arts-onderwijskundige verbonden aan het Wenckebach Instituut, Universitair Medisch Centrum Groningen.

Mw. drs. A.R. Yedema is trainingscoördinator/trainer, DÅSKA Consultants B.V., Zwolle.

Dr. P.M. Boendermaker is verbonden aan de Huisartsopleiding, Disciplinegroep Huisartsgeneeskunde, Universitair Medisch Centrum Groningen.

\section{Correspondentieadres:}

Dr. J. Pols, Wenckebach Instituut, Universitair Medisch Centrum Groningen, Postbus 30.001, 9700 RB Groningen, tel.:050-3611609, j.pols@oo.umcg.nl.

\section{Summary}

Introduction: During postgraduate training, residents in various disciplines must master General Competencies. Clinical teachers should know which of the residents' regular tasks and activities offer educational opportunities for which competencies. We endeavoured to fill the lack of overviews of residents' tasks and job responsibilities by compiling a list of residents' duties that was representative of most specialties and offered sufficient detail to do justice to salient differences between the four main groups of specialties, i.e. surgical specialties, general medical specialties, general practice, and public and occupational health.

Method: We compiled a list of tasks based on the observation of and interviews with residents in various specialty programmes, using a model of professional competencies as a frame of reference. Experts commented on the list and it was compared with relevant documentation. The resulting list was validated by an email survey among residents in the North and East Netherlands medical education region.

Results: 59 tasks and activities, derived from observation and interviews, formed the basis of the questionnaire. The overall response was 34\%. It was lowest among residents in public and occupational health (16\%) and residents in one general medical specialty were not reached. Seven tasks were modified and five new ones added, yielding a total of 64 tasks and activities.

Conclusion and discussion: We obtained a valid and adequately detailed overview of residents' tasks and activities. Despite some limitations, this list appears to be a feasible tool for matching learning opportunities offered by tasks to competencies to be acquired. This will be helpful in structuring postgraduate specialty training programmes. (Pols $J$, Yedema AR, Boendermaker PM. An exploration of the tasks and duties of junior doctors in specialty training programmes. Dutch Journal of Medical Education 2005;24(5):220-229.) 